\title{
A Case of Periorbital Necrotizing Fasciitis Occurred in Patient with Fungal Sinusitis
}

\author{
Dong Hwan Kim, Min Song Kim, Han Seok Yoo, and Jin Hyeok Jeong \\ Department of Otolaryngology-Head and Neck Surgery, College of Medicine, Hanyang University, Seoul, Korea
}

\author{
진균성 부비동염에 의해 발생한 안구 주위 괴사성 근막염 1예 \\ 김동환 · 김민송 · 유한석 · 정진혁 \\ 한양대학교 의과대학 이비인후-두경부외과학교실
}

\author{
Received August 30, 2016 \\ Revised October 18, 2016 \\ Accepted November 10, 2016 \\ Address for correspondence \\ Jin Hyeok Jeong, MD, PhD \\ Department of Otolaryngology- \\ Head and Neck Surgery, \\ College of Medicine, \\ Hanyang University, \\ 222-1 Wangsimni-ro, Seongdong-gu, \\ Seoul 04763, Korea \\ Tel $+82-31-560-2368$ \\ Fax +82-31-566-4884 \\ E-mail ent@hanyang.ac.kr
}

Orbital complications due to sinusitis usually occur in children and spread from the ethmoid or frontal sinusitis. Periorbital necrotizing fasciitis, which is an aggressive infection characterized by extensive necrosis and gas formation in the fascia and subcutaneous tissue, is uncommon as an orbital complication due to sinusitis. Because most of orbital complications of the fungal sinusitis occur from invasive fungal infection in immunocompromised patients, orbital complications due to non-invasive maxillary fungal ball in healthy patients are extremely rare, especially if the complication is periorbital necrotizing fasciitis. We report a case of periorbital necrotizing fasciitis that occurred in a healthy 44-year-old male patient with non-invasive fungal sinusitis, which was treated with a combination of intravenous antibiotics and endoscopic sinus surgery and ophthalmologic surgical treatment.

Korean J Otorhinolaryngol-Head Neck Surg 2018;61(1):56-60

Key Words Fungal sinusitis $\cdot$ Necrotizing fasciitis $\cdot$ Periorbit.

\section{서 론}

두경부영역에서 괴사성 근막염은 세균 감염으로 근막을 따 라 빠르게 진행하면서 인접한 피부, 피하조직, 근육 및 연부 조직의 광범위한 괴사와 조직 내 가스를 형성하는 중증 감염 성 질환으로 주로 당뇨와 같이 면역 기능이 저하된 환자에서 발생하지만 건강한 사람에서도 감염, 외상, 수술 등에 의해 드 물게 발생할 수 있다. ${ }^{1,2)}$ 비부비동염 환자에서 발생한 안구 주 위 괴사성 근막염은 아주 드문데 국내에서는 조절되지 않은 당뇨를 가진 환자 1 예 ${ }^{3}$ 와 치아 발치 후 발생한 환자에서 발생 한 1예 ${ }^{4}$ 만 보고될 정도로 아주 드문 질환이다.

진균성 부비동염에서 안구합병증은 모균증과 같이 침습성

This is an Open Access article distributed under the terms of the Creative Commons Attribution Non-Commercial License (http://creativecommons.org/licenses/by-nc/4.0) which permits unrestricted non-commercial use, distribution, and reproduction in any medium, provided the original work is properly cited.
일 경우 발생하는 경우가 대부분이며 비침습성인 진균구에 의 해 발생하는 경우는 매우 드물다. ${ }^{5)}$

저자들은 기저 질환 및 외상력이 없는 44세 남자 환자에서 비침습성 진균성 부비동염인 진균구에 의해 발생한 급성 부 비동염으로 인한 안구 주위 괴사성 근막염이 발생한 증례를 이비인후과와 안과적 수술과 약물치료로 치료한 경험을 문 헌 고찰과 함께 보고하는 바이다.

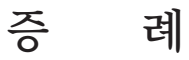

44세의 기저 질환이 없는 남자 환자가 좌측 안구와 안구 주 위의 종창 및 동통을 주소로 내원하였다. 증상은 내원 전날 저녁부터 시작되었으며, 발생 직후 타원 응급실에 내원하여 약물치료를 받았으나 당일 밤 증상이 급격히 악화되었고 시력 저하가 동반되어 다시 본원 응급실로 내원하였다. 내원 당시 환 
자는 콧물이나 코막힘 등의 부비동염 증상은 전혀 호소하지 않았으며 시력저하 및 안와 주위 동통을 강하게 호소하였다.

신체 검사상 좌측 안와주변으로 안면부의 발적과 종창이 관찰되었고, 내시경으로 본 비강 내에는 좌측 중비도 점막 의 종창이 관찰되었으나 그 외 특이소견은 관찰되지 않았다 (Fig. 1). 안과 검사상 좌측 시력은 나안 0.1 , 교정 0.1로 확인 되었으며, 좌측 안압은 $50 \mathrm{~mm} \mathrm{Hg}$ 이상으로 상승되어 있었 다. 혈액검사에서는 $\mathrm{WBC} 22,100, \mathrm{CPR} 13.83$ 으로 상승되어 있었고 $\mathrm{Hb} \mathrm{Alc}$ 는 6.3으로 정상으로 측정되었다. 내원 시 촬
영한 조영증강 안면 전산화단층촬영상 좌측 안와 주위, 뺨 과 이마부위에 심한 염증성 침윤소견과 안와 내 공기음영이 보였으나 명백한 농양 소견은 보이지 않았다. 좌측 상악동에 는 연부조직 음영 소견 및 석회화 소견이 보였으며 안와 하벽 에 작은 골결손으로 의심되는 부위가 관찰되었다(Fig. 2).

이에 안와 내 합병증이 동반된 진균성 부비동염이 의심되 어 내원 당일 즉시 전신마취하 내시경 부비동 수술을 시행하 였다. 소식자를 이용하여 상악동에 접근하자 회색의 생선 썩 는 양상의 악취가 나는 분비물이 흘러나왔고, 상악동 자연구
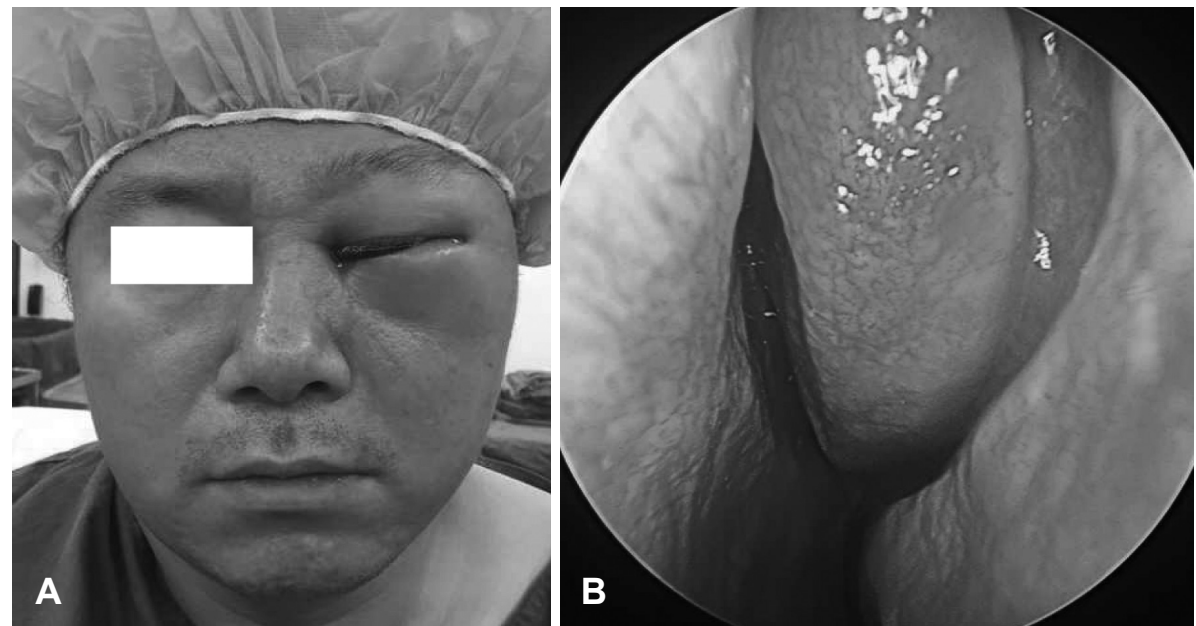

Fig. 1. Preoperative findings. Erythematous swelling on left periorbital and facial area (A). Endoscopic findings: left middle meatus blocked by edematous mucosa without discharge $(B)$
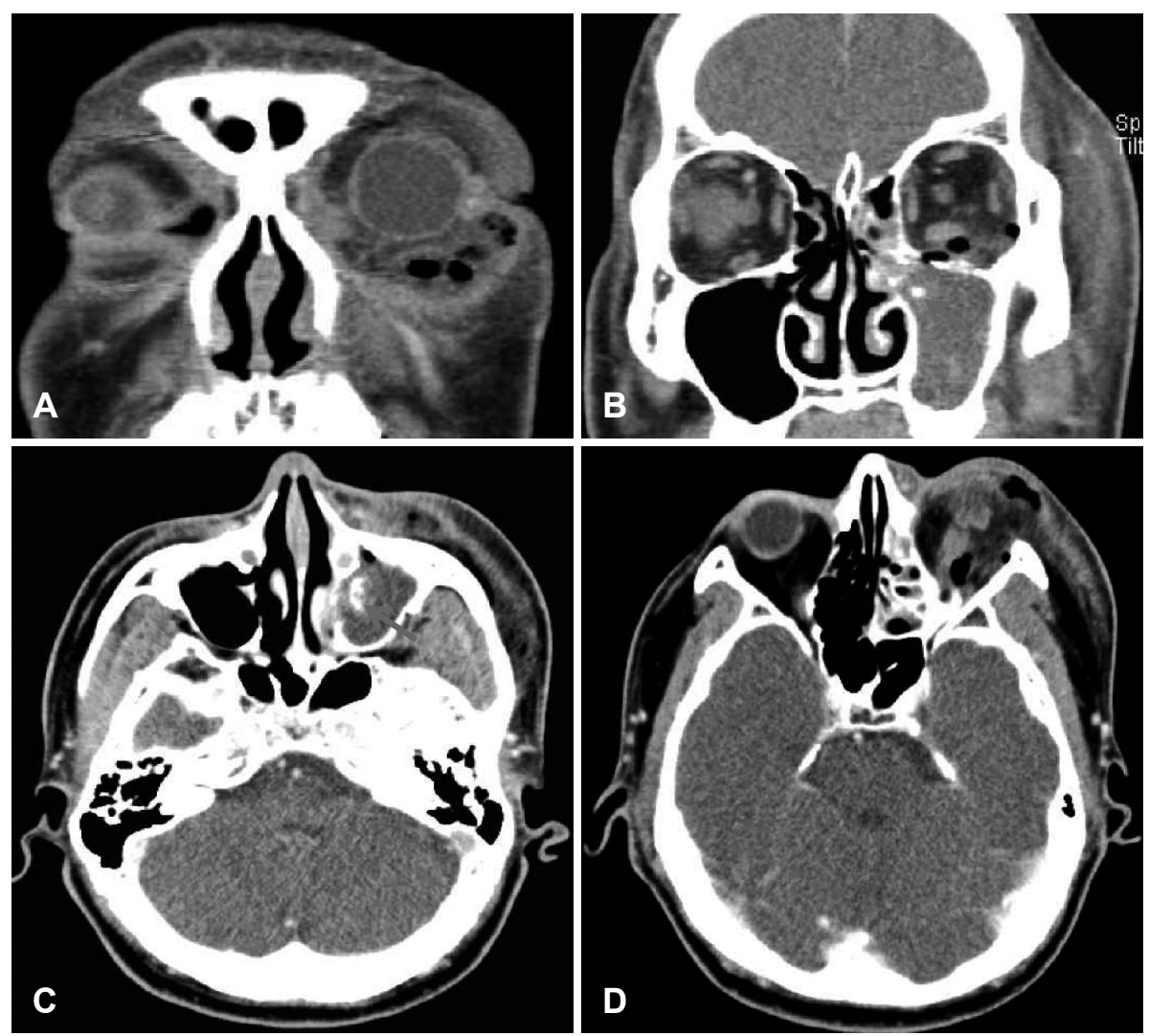

Fig. 2. Facial CT with contrast enhancement. Soft tissue infiltration with diffuse air bubble in left periorbital, adjacent cheek, forehead (A and $D$ ). Hyperdense material around the maxillary ostium with suspicious infraorbital bony erosion (arrow: hyperdense material, *suspicious infraorbital bony erosion) (B and $\mathrm{C}$ ). 
를 막고 있는 흑갈색의 진균구가 관찰되어 상악동의 입구를 넓혀준 후 제거하였다. 진균구는 상악동 자연구 근처에만 있 었고 상악동 내에는 회색의 생선 썩는 양상의 악취나는 분비 물로 가득차 있었고 상악동 내의 점막은 경부의 괴사성 근막 염 때 보이는 검은색의 괴사성 점막 소견을 보였다(Fig. 3). 침 습성 진균감염(invasive fungal infection) 여부를 확인하기 위해 상악동 내 괴사성 점막에서 조직검사를 시행하였다. 수 술 전 전산화단층촬영에서 의심하였던 안와 하벽의 골결손으 로 의심된 부분은, 수술 시에 눈을 눌러 보았을 때 특이소견이 관찰되지 않았다. 환자는 바로 입원하여 amoxicillin/clavulanic acid, 3rd cephalosporin, clindamycin 등의 경험적 정맥 항생제 투여를 시작하였고 안과로부터 원인 병변인 부비동에 대한 수술을 먼저하고 항생제 치료를 하면서 경과 관찰 후 안 과적 수술을 고려하겠다는 협진 결과를 받아 안과적인 수술 은 같이 시행하지 않았다. 수술시 상악동 점막에서 나간 조직 검사 결과는 침습성 진균감염이 아닌 만성 활동성 염증 (chronic active inflammation) 소견으로만 나왔고 상악동에 서 배출된 분비물에서 나간 세균배양검사와 항생제감수성검 사 결과는 Staphylococcus aureus 1+ 소견을 보였고 혐기성 세균검사는 검체 키트 사정으로 나가지 못했다.

수술 직후 안압과 통증은 다소 호전되었으나 저녁 무렵 다
시 안구 통증 악화를 호소하고 좌측 안압은 측정불가 상태가 되어 침상에서 국소마취하 외안각 절개술(canthotomy \& cantholysis)을 시행하였으며 이후 안압이 $31 \mathrm{~mm} \mathrm{Hg}$ 로 감소되었 다. 수술 후 2일째 좌안의 안압이 다시 $41 \mathrm{~mm} \mathrm{Hg}$ 로 상승하 고 시력 안전지수 $20 \mathrm{~cm}$ 로 악화되어 안과에서 전신마취하 안와 내 절개 및 배농술을 시행하였으며 외안각 절개술을 재 시행하였다. 수술 후 3일째 좌안의 안압이 $34 \mathrm{~mm} \mathrm{Hg}$, 시력 0.06으로 호전되었으며 수술 7일째 안압이 $21 \mathrm{~mm} \mathrm{Hg}$, 시력 0.5 , 수술 24일째 안압 $20 \mathrm{~mm} \mathrm{Hg}$, 시력 0.6으로 호전되었고 복시도 사라졌으며 안면의 종창도 모두 호전되었다(Fig. 4). 이비인후과 부비동 내시경 수술 시 나간 진균구와 상악동 점 막의 조직검사 결과는 aspergilloma와 활동성 점막 염증으 로 보고 받았다.

\section{고 찰}

두경부에서 발생하는 괴사성 근막염은 두 가지로 나눌 수 있는데 경부에서 발생하는 괴사성 근막염은 대부분 치성 감 염에 의해 발생하고 안면부에 발생하는 경우는 피부의 외상 으로 인해 많이 발생한다. ${ }^{6)}$ 주로 고령이나 당뇨, 알코올 중독, 만성 신부전 등과 같이 면역 기능이 저하된 환자에서 발생하
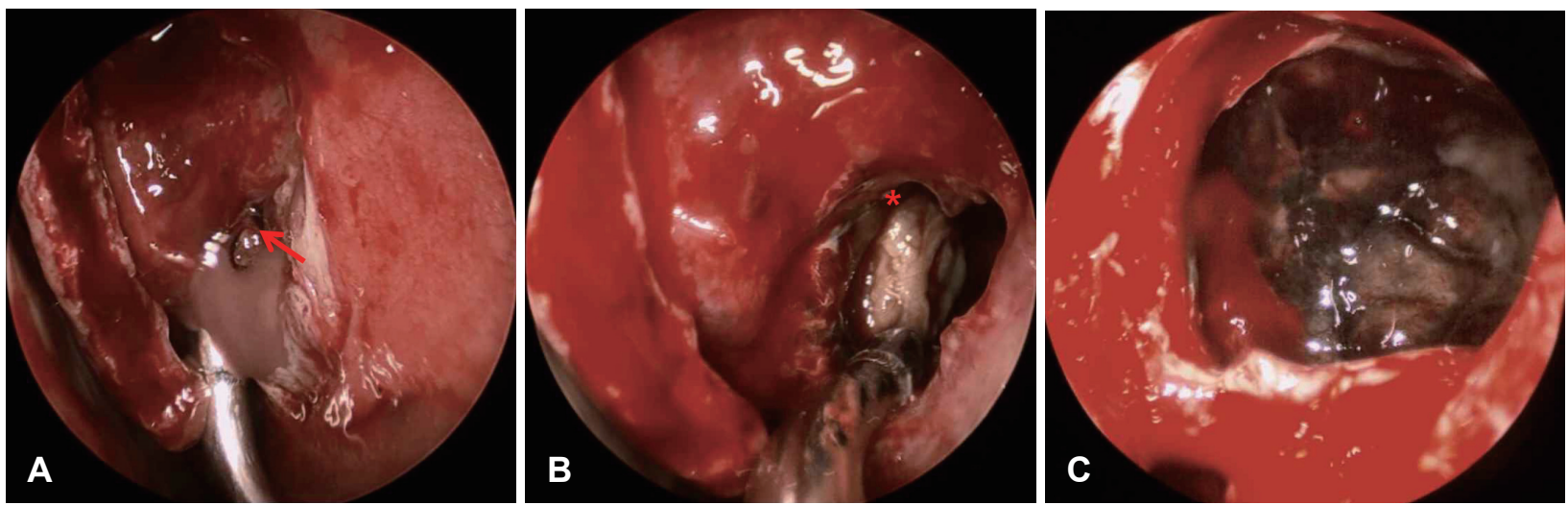

Fig. 3. Operative findings. Grayish, disgusting discharge (arrow) expelled out from left maxillary sinus (A). Fungal ball (*) around natural ostium of left maxillary sinus (B). Black colored severe necrosis on left maxillary sinus mucosa (C).
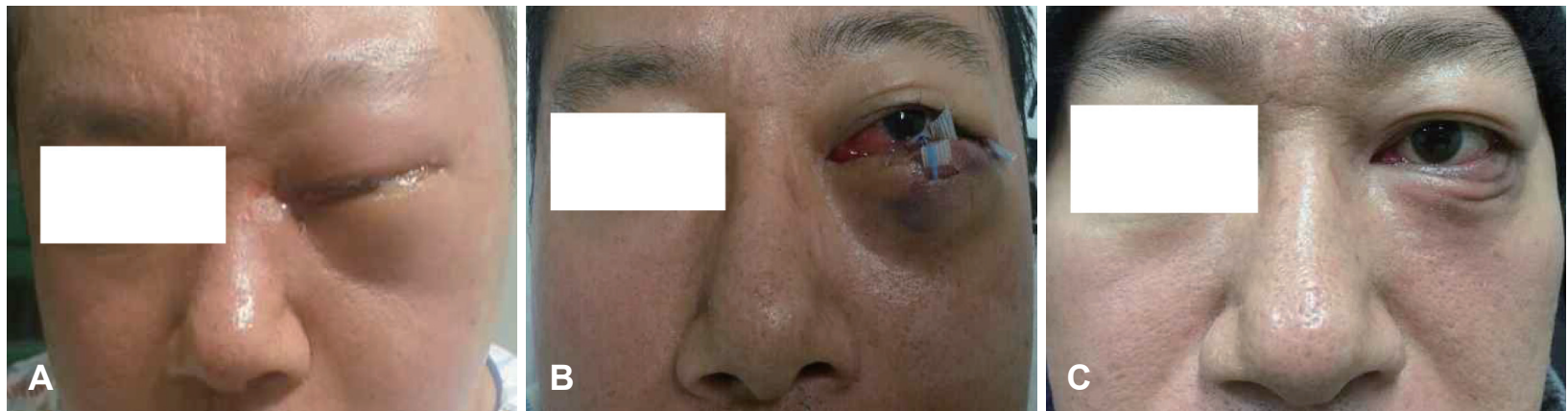

Fig. 4. Postoperative findings. POD\#0 after endoscopic sinus surgery (A). POD\#7 after orbital incision and drainage with canthotomy and cantholysis (B). POD\#24 facial photograph (C). 
나 건강한 사람에서도 발생할 수 있다. ${ }^{2)}$ 본 증례에서는 당뇨 와 같은 면역 기능저하와 관련된 기저 질환도 없고 외상도 없 는 건강한 젊은 남자에서 상악동에 발생한 진균구가 상악동 개구부를 막아 상악동 내 혐기성 세균 감염이 발생하고 안구 하벽을 통해 안구 내로 염증이 침범하여 안구 주위 조직에 괴 사성 염증으로 진행된 것으로 생각된다.

일측성 안구 주위 부종 및 발적, 통증이 있는 경우 부비동염 에 의한 안구합병증을 의심할 수 있는데 흔히 안와주위염, 안 와 봉와직염, 안와 골막하농양, 안와 농양, 그리고 해면정맥 동혈전염 등을 고려하고 진단한다. ${ }^{7)}$ 본 증례에서는 부비동염 의 안구합병증을 의심하여 조영증강 부비동 전산화단층촬 영을 시행하였고 위에서 기술한 안구합병증과는 다르게 안구 내 가스를 형성하며 급속도로 악화되는 괴사성 근막염의 소 견과 상악동의 진균구가 발견되어 응급으로 수술 결정을 하 였다. 따라서 부비동염의 안구합병증에서 봉와직염과 농양의 구별이 중요하지만 봉와직염과 괴사성 근막염의 구분도 필요 하다. ${ }^{8}$ 봉와직염은 염증이 피하지방층까지 파급되지만 괴사 성 근막염은 근막을 따라 파급되며 급속도로 진행되어 피부 괴사나 근염, 근괴사가 동반될 수 있고 봉와직염은 대부분 수 술적 치료 없이 항생제 치료로 호전되지만 괴사성 근막염은 항생제 치료와 함께 절개 및 배농, 변연절제술과 같은 수술적 치료가 필요하며 늦을 경우 치사율이 높다.,4) 본 증례에서는 피부괴사나 근괴사까지 진행하기 전에 빠른 진단과 수술, 약 물치료를 통해 치료를 시작하였다. 다만 안과적인 처치에 있 어서 초기에 외안각 절개술만 시행하고 약물치료 반응을 지켜 보기보다는 조기에 절개 및 배농을 고려하는 것이 좋았을 것 으로 생각된다.

괴사성 근막염을 의심할 수 있는 소견으로 Wong 등)은 1) 치성 감염이 경부 하방이나 전방 흥부로 진행되는 경우, 2) 조 직 내 가스의 비정상적인 축적이 있는 경우, 3) 감염이 급속도 로 빠르게 진행되는 경우, 4) 이환부의 피부가 변색되는 경우 를 들었다. 본 증례는 안구 주위의 병변으로 치성 감염과 관 련 없이 상악동의 진균구에 의해 상악동 내 혐기성 2 차 세균 감염이 발생하여 안구로 파급된 증례이지만 안구 조직 내 가 스와 하루만에 급속도로 빠르게 진행하는 양상으로 괴사성 근막염을 의심하였고 이를 근거로 빠른 치료를 시작하여 피 부까지 괴사되는 것을 막을 수 있었다. 조직 내 가스 음영이나 농양을 진단하기 위해서는 조영증강 전산화단층촬영이 필수 적이며 배농 시 생선 썩는 것 같은 심한 악취가 나는 특징이 있 는데 본 증례에서도 내시경 부비동 수술 시 생선 썩는 것 같은 심한 악취가 났고 일반적인 부비동염에서 보는 화농성 분비 물이 아닌 생선 썩을 때 나오는 분비물 같은 양상이었다.

안구 주위 괴사성 근막염의 주 합병증으로 심한 염증과 부
종에 의한 안압의 증가로 허혈성 괴사가 초래되어 시력 소실이 발생할 수 있다. ${ }^{10)}$ 본 증례에서도 안압계로 측정할 수 있는 범위를 초과하는 심한 안압 증가가 초래되어 응급으로 외안 각 절개술를 시행하여 안압을 낮추어 시력을 보존할 수 있었다.

괴사성 근막염의 치료에는 빠른 수술적 치료가 필수적인데 본 증례와 같이 부비동염과 연관된 경우 빠른 원인 인자에 대 한 부비동 내시경 수술뿐 아니라 안구에 대한 빠른 절개 및 배농, 근막 절개술이 필요하고 광범위 괴사가 일어났다면 광 범위한 괴사조직에 대한 변연절제술이 요구되며 치료에 대한 반응이 좋지 않을 경우 반복적인 수술이 필요할 수 있고 관련 된 진료과들 간의 협진이 필요하다.,4)

진균성 부비동염이 안구를 침범한 경우는 보통 침윤형 및 전격형인 경우가 대부분으로 주로 면역이 저하되거나 당뇨 환 자에서 발생하며, 주변 조직으로 침윤하는 특징을 보이고, 일 차적으로 수술을 통해 병변 부위의 광범위한 절제와 함께 전 신적인 항진균제의 정맥 투여가 필요하다. ${ }^{11)}$ 이와 달리 진균구 는 면역상태가 정상인에서 주로 발생하며 주변 조직으로 침 윤이 없어 수술적으로 진균구만 제거해 주면 되는 질환이다, 하지만 본 증례와 같이 진균구가 상악동 입구를 막는 경우에 는 상악동에 2차 세균 감염이 발생하고 특히 혐기성 세균 감 염이 되기 쉬운 환경을 유발하여 혼합감염이 발생하여 안구 로 침범하여 괴사성 근막염을 유발할 수도 있다는 것도 알고 있어야 할 것으로 생각된다. 일반적으로 부비동염에 의해 발 생하는 안구 염증은 골벽이 얇은 사골동에서 파급되는 경우 가 대부분이며 상악동 상벽의 경우는 비교적 골벽이 두꺼워 잘 발생하지 않는다. 그러나 본 증례와 같이 상악동 개구부가 진균구로 막힌 상태에서는 상악동 내 혼합감염에 의해 가스 를 형성하고 이로 인해 압력이 올라가면 상악동 상벽의 아주 미세한 골결손을 통해 염증이 안구 내로 파급될 수도 있을 것 으로 추정해 볼 수 있다.

본 증례는 괴사성 근막염이 주로 발생하는 환경인 당뇨와 같은 면역저하 상태도 아니고 원인 요소로 치성 감염도 없는 상태에서 상악동의 진균구에 의해 상악동 개구부가 막혀 발 생한 상악동 2차 세균 감염에 의해 안구로 침범된 증례이다. 일반적인 급성 부비동염과는 다른 심한 악취와 생선 썩을 때 나오는 듯한 분비물, 검은색으로 괴사된 부비동 점막, 안구 내 가스 발생과 급속도로 진행하는 염증으로 악화되는 임상 양상으로 진균성 부비동염에 의한 안구 주위 괴사성 근막염 으로 진단할 수 있었다. 이러한 경우 원인이 되는 부비동에 대 한 빠른 수술적 치료와 더불어 안구에 대한 적극적인 수술적 치료가 필수적이며 이를 통해 시력을 보존하고 안면부 괴사를 막을 수 있을 것으로 생각된다. 


\section{REFERENCES}

1) Wilson B. Necrotizing fasciitis. Am Surg 1952;18(4):416-31.

2) Yang YS, Lee HU, Kim JS, Lee JK, Hong KH. A clinical study of the cervical necrotizing fasciitis. Korean J Otolaryngol-Head Neck Surg 2005;48(8):1020-6.

3) Jeong HM, Jun KH, Lee SH, Lee JH. A case of periorbital necrotizing fasciitis occurred in a diabetes mellitus patient accompanied with chronic sinusitis with nasal polyp. Korean J Otorhinolaryngol-Head Neck Surg 2014;57(3):194-7.

4) Jung D, Yun M, Mo JH, Chung YJ. A case of periorbital necrotizing fasciitis occurred in patient with acute rhinosinusitis. Korean J Otorhinolaryngol-Head Neck Surg 2016;59(6):462-5.

5) Heier JS, Gardner TA, Hawes MJ, McGuire KA, Walton WT, Stock J. Proptosis as the initial presentation of fungal sinusitis in immunocompetent patients. Ophthalmology 1995;102(5):713-7.

6) Lazzeri D, Lazzeri S, Figus M, Tascini C, Bocci G, Colizzi L, et al. Periorbital necrotising fasciitis. Br J Ophthalmol 2010;94(12):1577-
85.

7) Younis RT, Lazar RH, Bustillo A, Anand VK. Orbital infection as a complication of sinusitis: are diagnostic and treatment trends changing? Ear Nose Throat J 2002;81(11):771-5.

8) Klabacha ME, Stankiewicz JA, Clift SE. Severe soft tissue infection of the face and neck: a classification. Laryngoscope 1982;92(10 Pt 1): $1135-9$.

9) Wong TY, Huang JS, Chung CH. Cervical necrotizing fasciitis of odontogenic origin: a report of 11 cases. J Oral Maxillofac Surg 2000; 58(12):1347-52.

10) Elner VM, Demirci H, Nerad JA, Hassan AS. Periocular necrotizing fasciitis with visual loss pathogenesis and treatment. Ophthalmology 2006;113(12):2338-45.

11) Kim BM, Kim KH. Successful treatment of rhino-orbital mucormycosis with posaconazole after combination of surgical treatment and amphotericin B. J Korean Ophthalmol Soc 2015;56(6):956-60. 